\title{
Internal Factors Affecting Albanian Banking Profitability
}

\author{
Eliona Gremi, PhD Candidate
}

\author{
Lecturer at Finance Account Department \\ Faculty of Economy, Elbasan, Albania \\ Email: elionagremi@yahoo.com, Mobile: 00355692028385
}

Doi:10.5901/ajis.2013.v2n9p19

\begin{abstract}
The purpose of this study is to analyze some of the more important internal factors that affect the profitability of commercial banks in Albania. The aim of this paper is to find out the relationship between the internal factors and bank profitability. Bank profitability is measured by Return on Assets (ROA) as a function of some important determinants taken in consideration in this research. Through this paper I would like to show how practical results seem to be equal to the empirical results. This paper analyzes the profitability of commercial banks in Albania over the time period from 2005 to 2012 for 12 commercial banks in Albania organize by 95 observations. This paper uses regression analysis fixed effect model to implicate the results with the respective hypotheses. The factors taken into consideration are Bank size, Loans, Deposit, Credit Risk, Interest income etc. The result from the analysis shows that, few of internal variables have significant influence on a bank's to total assets and some other have no significant effect on bank profitability.
\end{abstract}

Keywords: Bank profitability; commercial bank, bank size, regression model

\section{Introduction}

The financial system of the Albania is characterised by the dominant and specific role of the banking sector, since the capital market segment for long-term finance being illiquid and, in some cases underdeveloped, while non-bank financial intermediaries, such as life insurance companies and private pension funds, are still at under development. Ultimately the Albanian banking system has counted many changes during these years.

This paper seeks to examine the effect of bank-specific internal factors on the profitability of the Albanian banking industry over the period 2005-2012 for 12 commercial banks in Albania organize by 95 observations. This paper uses regression analysis fixed effect model to implicate the results with the respective hypotheses. The factors taken into consideration are Bank size, Loans, Deposit, Credit Risk, Interest income etc.

\section{Literature review}

In the literature, bank profitability, typically measured by the return on assets (ROA) and/or the return on equity (ROE), is usually expressed as function determinants. Determinants of bank profitability can be split between those that are internal and those that are external. Internal determinants of bank profitability can be defined as those factors that are influenced by the bank's management decisions and internal policy objectives. Management effects are the results of differences in bank management objectives, policies, decisions, and actions reflected in differences in bank operating results, including profitability.

Such profitability determinants are the level credit risk, provisioning policy, capital adequacy, expenses management and bank size. On the other hand, the external determinants, both industry-related and macroeconomic, are variables that reflect the economic and legal environment where the credit institution operates.

Changes in credit risk may reflect changes in the health of a bank's loan portfolio (Cooper 2003), which may affect the performance of the institution. Duca and McLaughlin (1990), among others, conclude that variations in bank profitability are largely attributable to variations in credit risk, since increased exposure to credit risk is normally associated with decreased firm profitability. This triggers a discussion concerning not the volume but the quality of loans made. In this direction, Miller and Noulas (1997) suggest that the more financial institutions are exposed to high-risk loans, the higher the accumulation of unpaid loans and the lower the profitability. 
Even though leverage (overall capitalization) has been demonstrated to be important in explaining the performance of financial institutions, its impact on bank profitability is ambiguous. As lower capital ratios suggest a relatively risky position, one would expect a negative coefficient on this variable (Berger, 1995b). However, it could be the case that higher levels of equity would decrease the cost of capital, leading to a positive impact on profitability (Molyneux, 1993). Moreover, an increase in capital may raise expected earnings by reducing the expected costs of financial distress, including bankruptcy (Berger, 1995b). Indeed, most studies that use capital ratios as an explanatory variable of bank profitability (e.g. Bourke, 1989; Molyneux and Thornton; 1992; Goddard et al., 2004) observe a positive relationship.

Finally, Athanasoglou et al. (2005), suggest that capital is better modelled as an endogenous determinant of bank profitability, as higher profits may lead to an increase in capital (also see Berger, 1995b). For the most part, the literature argues that reduced expenses improve the efficiency and hence raise the profitability of a financial institution, implying a negative relationship between an operating expenses ratio and profitability (Bourke, 1989).

However, Molyneux and Thornton (1992) observed a positive relationship, suggesting that high profits earned by firms may be appropriated in the form of higher payroll expenditures paid to more productive human capital. In any case, it should be appealing to identify the dominant effect, in a highly transitional banking environment like the SEE's.

Bank size is generally used to capture potential economies or diseconomies of scale in the banking sector. This variable controls for cost differences and product and risk diversification according to the size of the credit institution. The first factor could lead to a positive relationship between size and bank profitability, if there are significant economies of scale (see Akhavein et al. 1997; Bourke, 1989; Molyneux and Thornton, 1992; Bikker and Hu, 2002; Goddard et al., 2004), while the second to a negative one.

Haslem $(1968,1969)$ computed balance sheet and income statement ratios for all the member banks of the US Federal Reserve System in a two-year study. His results indicated that most of the ratios were significantly related to profitability, particularly capital ratios, interest paid and received, salaries and wages. He also stated that a guide for improved management should first emphasise expense management, fund source. A number of studies have concluded that expense control is the primary determinant of bank profitability. Expense management offers a major and consistent opportunity for profitability improvement.

With the large size and the large differences in salaries and wages, the efficient use of labour is a key determinant of relative profitability. Staff expenses, as conventional wisdom proposes, is expected to be inversely related to profitability because these costs reduce the "bottom line" or the total operations of the bank. The level of staff expenses appears to have a negative impact on banks" ROA in the study of Bourke (1989). However, Molyneux (1993) found a positive relationship between staff expenses and total profits. As he suggests high profits earned by firms in a regulated industry may be appropriated in the form of higher payroll expenditures.

External determinants of bank profitability are concerned with those factors which are not influenced by specific bank"s decisions and policies, but by events outside the influence of the bank. Several external determinants are included separately in the performance examination to isolate their influence from that of bank structure so the impact of the formers on profitability may be more clearly discerned.

Market concentration is not a random event but rather the result in industries where some firms possess superior efficiency. This hypothesis states that efficient firms increase in size and market share because of their ability to generate higher profits, which usually leads to higher market concentration. To distinguish between the two hypotheses, past researchers have included market share as an independent variable, with a positive coefficient usually supporting the EFS hypothesis (Smirlock, 1985). Smirlock models bank profitability as a function of market share, concentration, and an interaction term between market share and concentration (as well as several control variables) for over 2,700 unit state banks. However, this conclusion depends on whether market share can be considered as a proxy for efficiency of larger firms rather than as a measure of market power. An obvious solution to this problem is to include a measure of efficiency directly in the model. A necessary condition for the EFS hypothesis to be true is that efficiency must be positively related to concentration and/or market share.

Only recently, some authors [Berger and Hannan (1992), Goldberg and Rai (1996)] have tried to examine the implications of the EFS hypothesis regarding the effects of efficiency on market structure. Berger (1995) formulated models that included two measures of efficiency, X-efficiency and scale-efficiency, to test the structure-performance relationship. The positive relationship between profits and concentration is explained by lower costs achieved through either superior management or production processes.

Another variable used is some studies is the scale of regulation in several banking sectors. Jayaratne and Strahan (1998) find that operating costs and loan losses decrease sharply after states permit statewide branching and, to a lesser extent, interstate banking. The improvements following branching deregulation appear to occur because better banks 
grow at the expense of their less efficient rivals. Various studies have found that ownership characteristics may influence bank profitability. This is based on the view that management incentives differ under different forms of bank ownership [Short (1979), Bourke (1989), Molyneux (1993)].

Firstly, it creates great difficulty for the "assessment of loan decisions", since a loan arrangement which performs at the anticipated rate of inflation may turn out to be much more marginal if inflation is unexpectedly low and realised interest rates thus unexpectedly high. Uncertainty about future inflation may cause problems in planning and in negotiation of loans. Finally, high and variable inflation encourages bank financing investment in property markets, an investment strategy which may lead to market losses or great profitability according to the implemented monetary policy.

Performance is also influenced by numerous other forces that are frequently described as "demand" factors. While all demand factors cannot be identified or quantified, Kaufman (1965) believes that levels and changes in population and income may reasonably be assumed to be among the most important (also Yeats, 1974). Nelly and Wheelock (1997) conclude that state per capita income in US exerts a strong positive statistical effect on state bank earnings while income growth explains a relatively small amount of the variation in bank earnings. On the other hand, Heggestad (1977) found that per capita income does not affect bank profits. In any case, we suspect that per capita income may not be a good proxy for economic shocks that most directly affect bank earnings -for example, oil crises or commercial real estate crashes. A sharp downturn in a sector, such as real estate, could dramatically affect bank earnings without having a large impact on per capita income.

Zimmerman (1996) found that regional employment conditions are a significant contributing factor for both community bank asset quality and ROA. Haslem (1968) found that the effects of location on profitability are not important (these effects are important only to bank managers and others). Tirtiroglou and Daniels (2000) suggest strongly that the regional heterogeneity of US banking geography and its temporal dynamics are important determinants of bank performance. On the other hand, Zimmerman (1996) suggests that location is an important factor in determining profitability. Prasad and Harker (1997) found that in the competitive environment of retail banking, neither IT capital not IT labour investments should make significant impacts on the firm"s profitability. The results bear this hypothesis out: IT investment has zero or insignificant effect on bank profitability.

\section{Research methodology and the econometric model}

This study is based under panel data of period of 8 years from 2005 to 2012 for 12 important commercial bank in Albania. The primary data were taken by secondary resource from annual reports of each bank, annual report of Bank of Albania and other data published by Albanian Association of banks. The analized data is based on 95 observations in total which are from statistical point of view enough to test the hipotesis of the study.

The data are analysed by using linear regression estimated in form of:

Yit $=\beta 0+\beta 1 X 1 i t+\beta 2 X 2 i t+\beta 3 X 3 i t+\beta 4 X 4 i t+\beta 5 X 5 i t+$ uit

Where:

Yit------- represent ROA (return on assets of the bank $\mathrm{i}$ in time $\mathrm{t}$ )

X1it----- represent Bank SIZE (Log of assets of bank $\mathrm{i}$ in time $\mathrm{t}$ )

X2it----- represent Bank Loans (TL/TA represents ratio of Total Loans to Total Asset for bank i at time t)

X3it----- represent Credit Risk (NPLR= NPL/TL represents ratio of Total Non performing Loans to Total Asset for bank $\mathrm{i}$ at time $\mathrm{t}$ )

X4it------ represent Bank Deposits (TD/TA represents ratio of TotalDeposits to Total Asset for bank i at time t)

X5it------ represent TNI (TNI represents total net interest for bank $\mathrm{i}$ at time t)

u it------represent error term

\subsection{Hypothesis of the study}

The objective of this study is to find out the relationship between internal factors on Bank's profitability in top 12 banks of Albania. Based on the objective, the present study seeks to test the following main hypothesis:

$\mathrm{H} 0: \beta 1=\beta 2=\beta 3=\beta 4=\beta 5=0$ (none of the factors has not impact on bank profitability)

$\mathrm{H1}: \beta 1=\beta 2=\beta 3=\beta 4=\beta 5 \# 0$ (at least one factor has significant impact on bank profitability)

From the data analysed by Microfit for Windows, if we reject $\mathrm{HO}$ we have to verify alternative hypothesis with alternatives mini hypothesis:

H1-1 $\beta 1 \# 0$ ( Bank size has significant affect on bank profitability)

H1-2 $\beta 2 \# 0$ ( Bank loans has significant affect on bank profitability) 
H1-3 $\beta 3$ \#0 ( Credit Risk has significant affect on bank profitability)

H1-4 $\beta 4$ \#0 (Bank deposits has significant affect on bank profitability)

$\mathrm{H1}-5 \beta 5 \# 0$ (Bank interest has significant affect on bank profitability)

\subsection{Descriptive of variables}

In this study are not included all internal factors who affect bank profitability, but is limited to test the relationship between $\mathrm{ROA}$ ( dependent variable) and 5 independent variables taken in consideration:

- Return on Asset (ROA): The ROA is an indicator of bank's profit ability. It is calculated by dividing net income to total assets. ROA shows the profit earned per dollar of assets which reflects bank's management ability to utilize the bank's financial and real investment resources to generate profits [Ben Naceur (2003) and Alkassim (2005)].

- Size of Bank: The size of a bank is measured by total assets(loag asetes). The size of the bank is included in this study, as an independent variable, which account for size related economies and diseconomies of scale. In most of the finance literature, the total assets of the banks are used as a proxy for bank size. However, since the dependent variable in the model (ROA) was deflated by total assets it would be appropriate to take natural logarithm before including it in the model to be consistent with other ratios.

- Total Loans (TL) to Total Assets (TA): Asset composition (TL/TA), which is explained by total loans divided by total asset, provides a measure of income source and measures the liquidity of bank assets tied to loans. TL/TA is included in the study of profitability as an independent variable to determine the impact of loans on banks' profitability.

- Credit risk (measured by NPLR - Non Performing Loan Rate) Credi risk is represented by NPLR (Non Performing Loan divided by Total Loans) is one most important variables which have a significant effect to ROA of samples banks.

- Total Deposits (TD) to Total Assets (TA): The ratio of deposits to total assets is another liquidity indicator but is considered as a liability. Deposits are the main source of bank funding and hence it has an impact on the profitability of the banks. Deposits to total assets ratio is included as an independent variable in this study

- TNI/TA (Total Net Interest devided by Total Assets) is a measure of the difference between the interest income generated by banks or other financial institutions and the amount of interest paid out to their lenders (for example, deposits) divided by total assets, relative to the amount of their (interest-earning) assets. It is similar to the gross margin of non-financial companies.

\subsection{Results and estimation}

This section deals with the results of the study which include the descriptive statistics, econometric results and tests for multi- collinearity which is relevant for the study. Due to the diversity in operations and regulations, four of the local banks were not considered for analysis, as their services were restricted to specialized areas. These include 12 commercial bank of Albania more active to the banking industry. The descriptive statistics are calculated and presented in Table 1 for ready reference.

Table 1: The results of regression model

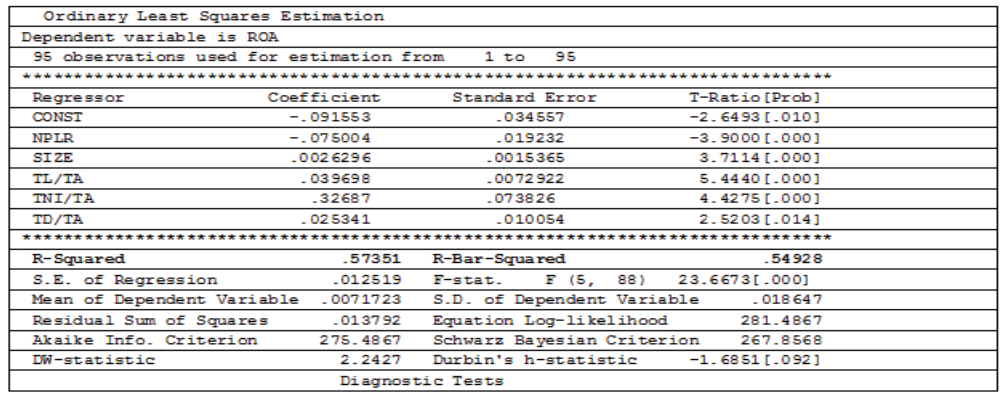


The value for the R-squared adjusted in the model is 0.55 which endorses that $55 \%$ of the variation in the dependent variable is explained by the independent variables taken in consideration of our model. The $45 \%$ variation in the dependent variable remains unexplained by the independent variables of the study, this is normal because many external factors who affect profitability are not taken in consideration in this study. The value for the F-statistic $(5,88)$ is 23.66 greater than Critical $\mathrm{F}$ and is significant endorsing the validity and stability of the model relevant for the study.

The results of the data analyze suggest that all the independent variables taken in model are significantly statistically so all the hypothesis are verify. The SIZE, TL/TA, TNI/TA and TD/TA have significant positive relation with ROA; meanwile NPLR has significant negative relation with ROA. The results are due to literature review.

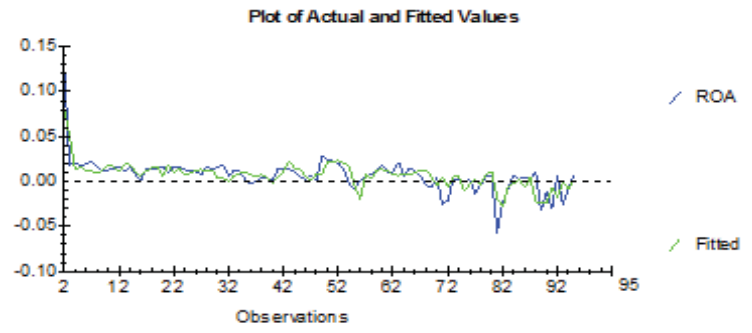

Table 2: Descreptive analysis

\begin{tabular}{|lcllrrr|}
\hline Sample period & $:$ & 1 to 95 & & & & \\
\hline Variable $(\mathbf{s})$ & $:$ & \multicolumn{1}{l}{ NPLR } & \multicolumn{1}{c}{ SIZE } & \multicolumn{1}{c|}{ KA } & \multicolumn{1}{c|}{ DA } & \multicolumn{1}{c|}{ TNIA } \\
\hline Maximum & $:$ & .42150 & 26.4920 & 1.3238 & 1.2546 & 1.5817 \\
\hline Minimum & $:$ & .0047000 & 21.2995 & .015000 & .32059 & -.048392 \\
\hline Mean & $:$ & .10065 & 24.4280 & .50765 & .76893 & .11411 \\
\hline Std. Deviation & $:$ & .077648 & 1.0960 & .20000 & .16044 & .26625 \\
\hline Skewness & $:$ & 1.4392 & -.64662 & .54939 & -1.0087 & 3.6485 \\
\hline Kurtosis - 3 & $:$ & 2.5081 & .69289 & 1.8719 & 1.2616 & 13.5719 \\
\hline Coef of Variation: & .77148 & .044865 & .39397 & .20866 & 2.3333 \\
\hline
\end{tabular}

Table 3: The correlation matrix

\begin{tabular}{|c|c|c|c|c|c|}
\hline \multicolumn{6}{|c|}{ Estimated Correlation Matrix of Variables } \\
\hline & NPLR & SIZE & $\mathrm{KA}$ & $\mathrm{DA}$ & TNIA \\
\hline NPLR & 1.0000 & & & & \\
\hline SIZE & .26387 & 1.0000 & & & \\
\hline $\mathrm{KA}$ & .14959 & .048674 & 1.0000 & & \\
\hline $\mathrm{DA}$ & .091701 & .41519 & -.19548 & 1.0000 & \\
\hline TNIA & -.097870 & -.11503 & .34319 & -.26070 & 1.0000 \\
\hline
\end{tabular}

\section{Conclusions}

This study investigates the impact of bank-specific characteristics on bank's profitability in the Albanian's banks for the 2005-2012 periods. Individual bank characteristics (internal factors) are considered as determinants of bank profitability in Albania. Banks with greater size, Total Assets, Loans, Deposits and net interes are perceived to have more safety and such an advantage can be translated into higher profitability.

Our findings in this regards are:

- Higher total assets may necessarily lead to hig her profits. The positive coefficient of size, significant at the 5 percent level, indicates that this relation is positive related to ROA. An increase of $1 \%$ to total assets increases 0.02 ALL to profitability of banks.

So H1-1 $\beta 1$ \#0 (Bank size has significant affect on bank profitability)—Accepted 
- Higher loans contribute towards profitability but their impact is significant that reveals that more dependence on one major asset, may lead to profitability but with less significant impact on overall profitability. An increase of $1 \mathrm{ALL}$ to TL/TA will increases $0.03 \mathrm{ALL}$ to profitability of banks.

So H1-2 $\beta 2$ \#0 (Bank loans has significant affect on bank profitability)—Accepted

- One major finding was the negative relationship of NPLR towards profitability when one of the banks showed a loss. An increase of $1 \mathrm{ALL}$ to NPLR will decreases $0.07 \mathrm{ALL}$ to profitability of banks.

So H1-3 33 \#0 (Credit Risk has significant affect on bank profitability)---- Accepted

- Total deposit to total assets and total equity to total assets showed a positive and significant relationship with profitability indicator ROA. An increase of $1 \mathrm{ALL}$ to TD/TA will increases $0.02 \mathrm{ALL}$ to profitability of banks.

So, H1-4 $\beta 4$ \#0 (Bank deposits has significant affect on bank profitability)-Accepted

- Total Net Interest to total assets showed a positive and significant relationship with profitability indicator ROA. An increase of $1 \mathrm{ALL}$ to TD/TA will increases $0.3 \mathrm{ALL}$ to profitability of banks.

So, $\mathrm{H} 1-5$ $\beta 5 \# 0$ (Bank interest has significant affect on bank profitability) -Accepted

\section{References}

D. Delis (2005). "Bank-specific industry- specific and macroeconomics determinants of bank profitability." Bank of Greece Working Paper 25, June.

Baltagi, B.H. (2001). Econometric Analysis of Panel Data. John Wiley \& Sons, Chichester.

Berger, A. (1995a). "The profit - structure relationship in banking: Tests of market-power and efficient-structure hypotheses." Journal of Money, Credit and Banking27, 404-431.

Berger, A. (1995b). "The relationship between capital and earnings in banking." Journal of Money, Credit and Banking 27, 432-456.

Bikker, J.A. and J.W.B. Bos (2005). "Trends in competition and profitability in the banking industry: A basic framework." SUERF - The European Money and Finance Forum, 2005/2.

Bonin, J.P., Hasan, I. and P. Wachtel (2005). "Bank performance, efficiency and ownership in transition countries." Journal of Banking and Finance29, 31-53.

Demirguc-Kunt, A. and H. Huizinga (2000). "Financial structure and bank profitability." World Bank Mimeo.

Duca, J. and M. McLaughlin (1990). "Developments affecting the profitability of commercial banks." Federal Reserve Bulletin, July.

Edwards, F. (1977). "Managerial objectives in regulated industries: Expense-preference behaviour in banking." Journal of Political Economy 85, 147-162.

Goddard, J., Molyneux, P. and J. Wilson (2004). "Dynamics of growth and profitability in banking." Journal of Money, Credit and Banking 36, 1069-1090.

Miller, S. and A. Noulas (1997). "Portfolio mix and large-bank profitability in the USA." Applied Economics 29, 505-512.

Molyneux P. (1993). "Structure and performance in European banking." Doctoral Dissertation, University of Wales, Bagnor.

Molyneux, P. and J. Thornton (1992). "Determinants of European bank profitability: A note." Journal of Banking and Finance 16, 11731178.

Neely, M. and D. Wheelock (1997). "Why does bank performance vary across states?" Federal Reserve Bank of St. Louis Review, pp. 27-38.

www.aab.al/al/statistics

www.bankofalbania.org/annual report 2005-2012

www.raiffeisen.al/annual report 2005-2012

www.tiranabank.al/annual report 2005-2012

www.bkt.com.al/annual report 2005-2012

www.bankacredins.al/annual report 2005-2012

www.intensasanpaolo.al/annual report 2005-2012

www.unionbank.al/annual report 2005-2012

www.fibank.al/annual report 2005-2012

www.nbg.al/annual report 2005-2012 


\section{Apendices}

Residuals and Fitted Values of Regression

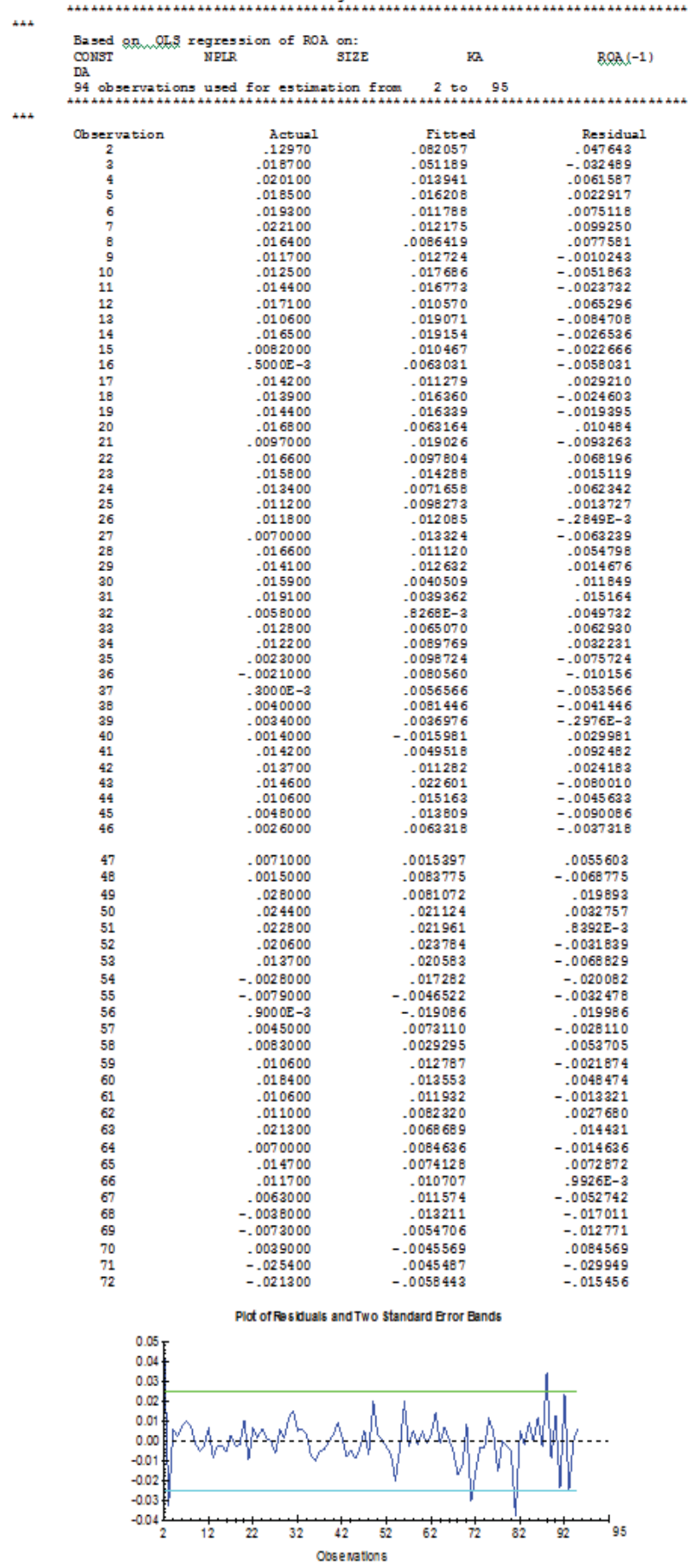

